\title{
Co-integration and Causality Analysis of the Financial Development on Urbanization
}

\author{
Yuzhong Sun \\ College of Economics and Management \\ China Agricultural University \\ Beijing, 100083 China \\ syzdqhit@163.com
}

\author{
Chuncheng Liu \\ College of Economics and Management \\ China Agricultural University \\ Beijing, 100083 China \\ liucc@263.net
}

\begin{abstract}
This paper examines how financial development affects level of urbanization in China. Using a co-integration test and VEC model through time series data from 1991 to 2012, it is pointed that there is a long-term equilibrium relationship between the financial development and the level of urbanization. Furthermore, the research presents that the financial development scale has positive effect on the level of urbanization in short term, but the financial development structure and the financial development efficiency have negative effects on the level of urbanization in short term. The results suggest that in order to significantly promote the level of urbanization, current financial reform in China should enlarge the financial development scale, optimize financial structures, strengthen governance structure of state-owned bank and accelerate market-oriented reforms of interest rates.
\end{abstract}

Keywords-financial development; urbanization; co-integration; VEC model; causality analysis

\section{INTRODUCTION}

Urbanization level is an important symbol of the level of economic development in a country or region. Historical experience of urbanization in the world shows that urbanization is not only the result of economic development, but also the inevitable path and important driving force of economic development.

A large number of studies show that there is a significant positive correlation relationship between urbanization and economic growth (Eric E. Lampard 1955 \& B. Renaud 1981). One hand, the mutual relationship between the urbanization and economic growth is reflected by economic growth promoting the urbanization process in the long-term $(\mathrm{H}$. B. Chenery et al. 1975), on the other hand, because of the external economy from the city, urbanization is not only decided by the industrialization and economic growth, but also constitute an important driving force of industrialization and economic growth(UN. 2011a \& K.C. Seto 2013).

Finance is the core component of the modern economy. Financial development has a huge role in promoting economic growth(R. G. King, R. Levine 1993 \& M. Kandil et al. 2015).

In the discussion of the impact of financial support to urbanization, early scholars' research is conducted from a qualitative point of view. After 2002, Chinese scholars began to pay attention to the numerical relationship between the level of urbanization development and financial development. Although the selection of the indicators is different, the measurement method is not the same, but the conclusion is consistent: there is a clear long-term equilibrium relationship between the level of financial development and the level of urbanization (W. Nan, Z. Xiaotong 2011). It should be particularly concerned financial development has a greater role in promoting urbanization relative to the promotion of financial development of urbanization.

Although a large number of studies have shown that there is a long-term equilibrium relationship between the level of financial development and the level of urbanization. But on one hand taking into account the lag of China's financial development environment, the market position of the different financial development indicators is not the same and the impact of them on the current urbanization process should be different. On the other hand, the reform of the financial system should be a gradual process; it can play a multiplier effect to find a clear focus on reform. Based on this, the paper further studies the relationship between the financial development and the urbanization, so as to promote the urbanization and determine the reform focus of the financial system.

\section{THEORETICAL FRAMEWORK AND HYPOTHESIS}

The framework of this paper is based on development economics, urban economics and financial development theory. The development economics theory points out that it is the only way of economic development with industrialization and urbanization promoting each other. The developing countries take the initiative urbanization strategy instead of the developed countries achieving that naturally. The government's policies and various institutional arrangements must take into account the structural characteristics of different levels of development to avoid the distortion or ineffectiveness from the government's excessive intervention in the economy (L. Yifu 2010).

Financial development theory reveals the importance of the development of the financial system to the economic growth. Many developing countries use various means to carry out a lot of intervention to the financial system. It has led to obvious financial repression despite some results for government's wrong policy. In order to avoid the same mistake we must further study the relationship between financial development and urbanization, especially the long 
and short term relationship between the level of urbanization in the region and the various indicators of the financial development. This is the basis for formulating the development of financial development policies to effectively promote the coordinated development of economy and urbanization. Based on this, this paper puts forward the following hypothesis:

Hypothesis 1: there is a long-term equilibrium relationship between the level of financial development and urbanization level.

Hypothesis 2: the scale of financial development has positive effect on the level of urbanization; the optimization of the structure of financial development, the improvement of the efficiency of financial development has positive effect on the level of urbanization.

\section{METHODOLOGY AND VARIABLE DEFINITIONS}

The long and short term relationship between the level of urbanization and the level of the financial development are tested in this paper with establishing the VEC model, impulse response analysis and variance decomposition on the base of unit root test, co-integration test.

Taking into account the availability of data, we define the following variables:

\section{A. Urbanization Variables}

We use urbanization rate (Urban) which is the proportion of urban population in the total population as the indicator of the level of urbanization.

\section{B. Financial Development Variables}

There are three types of indicators to measure the level of financial development, the scale indicators of financial development, the structure indicators of financial development, and the efficiency indicators of financial development.

We use financial related rate $(\mathrm{Fd})$ which is the ratio of financial institution loans to GDP as the scale indicator of financial development.

Taking into account the important position of the banking system and the state-owned banks in the entire financial system, especially the importance of the loan in developing countries, market concentration in banking (Fs) is used as the structure indicator of financial development which is the ratio of the loan of state-owned commercial banks to the bank's total loan.

The ratio of loans to deposits $(\mathrm{Fe})$ is used as the efficiency indicator of financial development.

\section{Control Variables}

There are a lot of other variables that affect the level of urbanization. We used the ratio of the national fiscal expenditure to GDP $(\mathrm{Fc})$ as the control indicators considering this research issue about the impact of capital on the level of urbanization.
TABLE I. DESCRIPTIVE Statistics OF VARIABLES

\begin{tabular}{|c|c|c|c|c|c|}
\hline & Lurban & Lfd & Lfs & Lfe & Lfc \\
\hline MEAN & -0.4241 & 0.0086 & -0.2420 & -0.0918 & -0.7844 \\
\hline MAX & -0.2792 & 0.0837 & -0.0858 & 0.0700 & -0.6153 \\
\hline MIN & -0.5695 & -0.0812 & -0.3538 & -0.1865 & -0.9526 \\
\hline STD & 0.0965 & 0.0484 & 0.0769 & 0.0814 & 0.1054 \\
\hline SKEWNSS & -0.0856 & -0.2422 & 0.4562 & 0.5669 & -0.1439 \\
\hline KURTOSIS & 1.6476 & 2.3019 & 2.5215 & 2.1144 & 1.8800 \\
\hline P VALUE & 0.4267 & 0.7182 & 0.6147 & 0.3872 & 0.5417 \\
\hline
\end{tabular}

The study period selected ranges from 1991 to 2012, and the annual data "China Statistical Yearbook" and "new China 60 years of statistical data compilation". In order to avoid the different variance, the data is processed by the logarithm, and the variables are set to Lfd, Lfs, Lfe, Lfc, Lurban. The descriptive statistics of the above variables are shown in Table I . The results show that the data is not abnormal values, and the variables are in normal distribution.

\section{RESULTS AND DISCUSSION}

\section{A. Stationarity Tests}

First of all, the variables are analyzed by graph. The results showed that there is a significant time trend.

Table II present the results of the unit root test for the variables used in the study for their levels and first differences. it may lead us to the conclusion that all the variables are stationary at Level 1 . Hence, all the variables in the study are integrated of order 1 .

\section{B. Co-integration Test}

After having established the time series properties of the data, the test for presence of long-run relationship between the variables using the Johansen co-integration approach was applied to the data which determined the number of cointegrated vectors for any given number of non-stationary variables of the same order.

TABLE II. UNIT ROOT TEST RESULTS

\begin{tabular}{|c|c|c|c|c|}
\hline Variable & $(\mathbf{C}, \mathbf{T}, \mathbf{K})$ & T statistics & $5 \%$ value & Results \\
\hline Lurban & $(\mathrm{C}, \mathrm{T}, 0)$ & -0.9545 & -3.6449 & Non stationary \\
\hline Slurban & $(\mathrm{C}, 0,0)$ & -3.3029 & -3.0206 & stationary \\
\hline Lfd & $(\mathrm{C}, \mathrm{T}, 1)$ & -3.3046 & -3.6584 & Non stationary \\
\hline$\Delta \mathbf{L f d}$ & $(\mathrm{C}, 0,1)$ & -3.5892 & -3.0299 & s stationary \\
\hline Lfs & $(\mathrm{C}, \mathrm{T}, 2)$ & -3.2812 & -3.6736 & Non stationary \\
\hline$\Delta \mathbf{L f s}$ & $(\mathrm{C}, 0,3)$ & -5.6408 & -3.0521 & stationary \\
\hline Lfe & $(\mathrm{C}, \mathrm{T}, 0)$ & -0.7385 & -3.6449 & Non stationary \\
\hline$\Delta l f e$ & $(\mathrm{C}, 0,0)$ & -3.6454 & -3.0206 & stationary \\
\hline Lfc & $(\mathrm{C}, \mathrm{T}, 1)$ & -0.9501 & -3.0206 & Non stationary \\
\hline$\Delta \mathbf{L f c}$ & $(\mathrm{C}, 0,4)$ & -5.1396 & -3.0655 & stationary \\
\hline
\end{tabular}


TABLE III. UNRESTRICTED CO-INTEGRATION RANK TEST (TRACE)

\begin{tabular}{|c|c|c|c|c|}
\hline $\begin{array}{c}\text { Hypothesized } \\
\text { No. of CE(s) }\end{array}$ & Eigenvalue & Trace Statistic & 0.05Critical Value & Prob.** \\
\hline None * & 0.9425 & 120.3284 & 69.8188 & 0.0000 \\
\hline At most 1 * & 0.8571 & 63.19425 & 47.8561 & 0.0010 \\
\hline At most 2 & 0.5341 & 24.27283 & 29.7971 & 0.1892 \\
\hline At most 3 & 0.3566 & 8.9941 & 15.4947 & 0.3659 \\
\hline At most 4 & 0.0086 & 0.1735 & 3.8414 & 0.6770 \\
\hline
\end{tabular}

TABLE IV. UNRESTRICTED CO-INTEGRATION RANK TEST (MAXIMUM EIGENVALUE)

\begin{tabular}{|c|c|c|c|c|}
\hline $\begin{array}{c}\text { Hypothesized } \\
\text { No. of CE(s) }\end{array}$ & Eigenvalue & $\begin{array}{c}\text { Max-Eigen } \\
\text { Statistic }\end{array}$ & 0.05Critical Value & Prob.** \\
\hline None * & 0.9425 & 57.1341 & 33.8768 & 0.0000 \\
\hline At most 1 * & 0.8571 & 38.9214 & 27.5843 & 0.0012 \\
\hline At most 2 & 0.5341 & 15.2786 & 21.1316 & 0.2698 \\
\hline At most 3 & 0.3566 & 8.8206 & 14.2646 & 0.3014 \\
\hline At most 4 & 0.0086 & 0.1735 & 3.8414 & 0.6770 \\
\hline
\end{tabular}

On observing the statistic value from Table III and Table IV, the statistic value is greater than the critical value at both $5 \%$ confidence levels under number of co-integrating equations equals none, thus rejecting null hypothesis and accepting that there exists more than 1 co-integrating vector. However, the hypothesis was accepted at most 2 cointegrating equations at $5 \%$ level. Hence, the co-integration results thus suggest the existence of long term relationship among the variables of Lfd, Lfs, Lfe, Lfc, Lurban.

The co-integrating equation is Equation (1) as follows. The number of the brackets is the standard deviation.

$$
\begin{aligned}
\text { Lurban }= & 0.224277 L f d-0.418336 L f s-0.475896 L f e+0.120843 L f c \text { (1) } \\
& (0.03010) \quad(0.02647) \quad(0.03363)
\end{aligned}
$$

There is a long-term equilibrium relationship in Lfd, Lfs, Lfe Lfc and Lurban. The financial related rate (Lfd) and the fiscal expenditure ratio (Lfc) have more significant positive effects to raise the level of urbanization; and the banking market concentration (Lfs), loan to deposit ratio (Lfe) have more significant negative effects to raise the level of urbanization.

The positive effect of the variables Lfd and Lfc on urbanization is consistent with expectation. During the current urbanization process, a large amount of money required for industrial development, infrastructure construction comes from the financial institutions loans. The increasing of $\mathrm{Lfd}$ inevitably means the increasing of the ability of financial system support for urbanization. And the positive role of Lfc in urbanization process shows the government's leading role in the process of urbanization.

The negative effect of Lfs on the level of urbanization is also consistent with expectations. On the one hand, the nonstate-owned banks are more flexible and more adaptable than the state-owned banks. It is of great significance for promoting the private economy and improving the financing environment of small enterprises to improve the proportion of non-stateowned banks in the banking sector, reduce the concentration of banking industry, and to increase the supply of financial services. The development of private economy plays a great role in promoting urbanization. On the other hand, it also shows that the low efficiency of state-owned banks in the allocation of credit funds.

The negative effect of Lfe on the level of urbanization is contrary to expectation. This abnormal phenomenon shows that banks' large loan does not achieve the expected investment income in china, especially for state-owned banks, the low level of capital allocation ability hinders the improvement of the level of Urbanization. This is the main reason of higher loan ratio is corresponding to lower the level of urbanization.

\section{Granger CausalityTest based on VECM Model}

Co-integration analysis can only show that at least there is a one-way causal relationship between the variables. In order to further explain the cause and effect relationship between the variables in the short term, the further test of the variables is needed.

The traditional Granger causality test is based on the VAR model, but it is not suitable for the sequence of non-stationary which has a co-integration relationship. For that, we can consider the use of the Granger causality test based on VECM model. According to the Granger representation theorem, any non-stationary variables that exist in co-integration relationship can be explained by the error correction model (ECM) to explain the short-term non equilibrium relationship between the variables. Vector error correction model (VECM) is a VAR model with co-integration constraints, which has the same lag phase as the co-integration test. The Granger causality test based on VECM model uses the Wald test method, that is, the significance of the endogenous variables in each equation in the VECM model is tested, and the direction of the causal relationship between the variables is judged according to the output statistics. The test results are shown in the Table V.

Table $\mathrm{V}$ shows that the $\mathrm{P}$ values are significantly less than $5 \%$, which indicates that the variables Lfd, Lfs, Lfe and Lfc are the Granger causes of variable Lurban. That is, the shortterm changes of financial related rate, banking industry concentration, deposit ratio and proportion of expenditure will cause fluctuations in the level of urbanization.

TABLE V. GRANGER CAUSALITY TEST RESULTS

\begin{tabular}{|c|c|}
\hline Null hypothesis & Probability \\
\hline $\mathrm{D}(\mathrm{Lfd})$ does not granger csuse D(Lurban) & $0.0181^{*}$ \\
\hline $\mathrm{D}(\mathrm{Lfs})$ does not granger csuse D(Lurban) & $0.0216^{*}$ \\
\hline $\mathrm{D}(\mathrm{Lfe})$ does not granger csuse D(Lurban) & $0.0028^{*}$ \\
\hline $\mathrm{D}(\mathrm{Lfc})$ does not granger csuse D(Lurban) & $0.0016^{*}$ \\
\hline
\end{tabular}

\section{Impulse Response and Variance Decomposition}

Granger causality test can only indicate whether there is a causal relationship between the variables, It can't reveal the influence of the change of a given variable to the other variables in the system is positive or negative, as well as how long the effects produced by the change of the variable lasts in 
the system. For this problem, we can establish the impulse response function and variance decomposition to obtain the information.

The impulse response function describes the response of an endogenous variable to the variation of the error. The principle is to increase the impact of a standard deviation on the perturbation terms, and to observe its effect on the current value and future value of the endogenous variable. The variance decomposition is the importance of evaluating the impact of different structures by analyzing the contribution of each structural impact on the internal variable.

Fig 1 is the effects of the variables produced by using impulse response function; table 6 is the results of the variance decomposition.

The findings from innovation accounting support the results obtained from the co-integration relationship and shortrun dynamic analysis. With the 10-week forecasting horizon, the results of variance decomposition and impulse response function are reported in Table VI and Figure 1. The results show Lfs can explains over 61 percent of the forecast error variance of Lurban, while leaving about 25 percent for $\mathrm{Lfd}$ and 8 percent for Lfe; Lurban explains 3 percent of its forecast error variance, the preponderance of its own past values. Lfc only 1 percent of the forecast error variance of Lurban respectively

TABLE VI. GRANGER CAUSALITY TEST RESULTS

\begin{tabular}{|c|c|c|c|c|c|}
\hline Period & Lurban & Lfs & Lfd & Lfe & Lfc \\
\hline 1 & 100.0000 & 0.0000 & 0.0000 & 0.0000 & 0.0000 \\
\hline 2 & 81.7184 & 5.7180 & 3.0557 & 1.6346 & 7.8731 \\
\hline 3 & 37.9781 & 43.6215 & 5.3991 & 5.4337 & 7.5676 \\
\hline 4 & 18.9828 & 59.2231 & 7.3901 & 7.1106 & 7.2931 \\
\hline 5 & 10.1367 & 65.2063 & 11.3133 & 8.0953 & 5.2481 \\
\hline 6 & 6.5386 & 64.8585 & 16.3683 & 8.4285 & 3.8059 \\
\hline 7 & 4.8867 & 63.3314 & 20.5678 & 8.4921 & 2.7218 \\
\hline 8 & 4.1633 & 62.1428 & 23.1836 & 8.4314 & 2.0786 \\
\hline 9 & 3.8993 & 61.5872 & 24.4981 & 8.3645 & 1.6508 \\
\hline 10 & 3.9112 & 61.1132 & 25.3135 & 8.2942 & 1.3677 \\
\hline
\end{tabular}
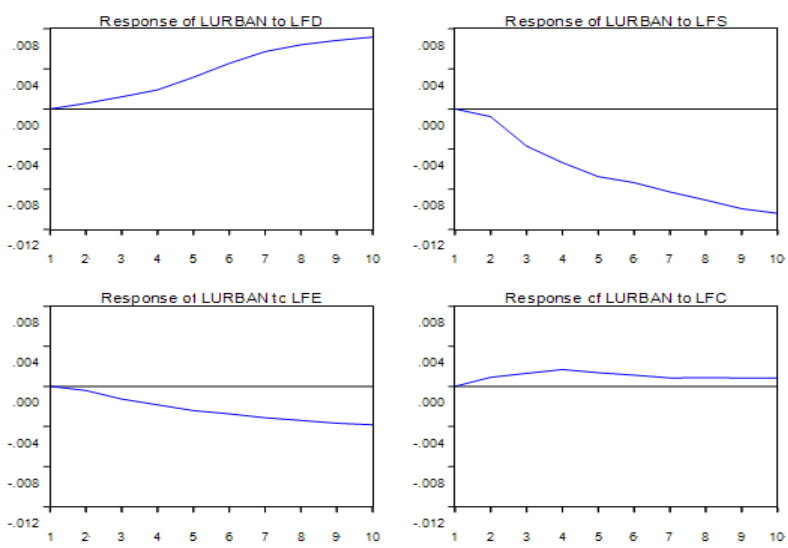

Fig. 1. Response to Cholesky One S.D. Innovations

\section{CONClusions And Policy ReCOMMENDATIONS}

This study explores the effects of financial development on urbanization it appears that Granger causality runs one way from the level of financial development to the level of urbanization. The co-integration analysis suggests that Lfd and Lfc have positive long-run effects on Lurban in contrast to Lfs and Lfc. Furthermore, it is worth noting that the effects of Lfs and Lfd on Lurban are more significant than Lfe and Lfc.

The policy implication inferred from the study points that it can enhance the support of finance market for urbanization by increasing the supply of financial institutions and reducing the concentration of banking markets. Also, by speeding up the reform of the interest rate market, expanding the scale of the loan of financial institutions, improving the rate of return on loans, urbanization process can be further accelerated. Loan to deposit ratio (Lfe) and urbanization level (Lurban) present reverse relationship. This abnormal phenomenon can be changed by accelerating the reform of the internal governance of the state-owned banks.

\section{REFERENCES}

[1] E. E. Lampard, "The history of cities in the economically advanced areas," Economic Development and Cultural Change. Chicago, vol. 3, pp. 81-136, February 1955.

[2] B. Renaud, National urbanization policy in developing countries, London: Oxford University Press, 1981, pp. 98.

[3] H. B. Chenery, M. Syrquin, H. Elkington, Patterns of development, 1950-1970, London: Oxford University Press, 1975, pp. 43-77.

[4] UN. (2011a). United Nations Statistics Division, National Accounts Main Aggregates Database. http://unstats.un.org/unsd/snaama/

[5] K.C. Seto, S. Parnell, and T. Elmqvist, Urbanization, biodiversity and ecosystem services: Challenges and opportunities, Dordecht: Springer, 2013, pp. 1-10.

[6] R. G. King, R. Levine, "Finance and growth: Schumpeter might be right," The Quarterly Journal of Economics. London, vol. 108, pp. 717737, March 1993.

[7] M. Kandil, M. Shahbaz, S. Nasreen, "The interaction between globalization and financial development: new evidence from panel cointegration and causality analysis", Empirical Economics. Vienna, vol. 49, pp 1317-1339, December 2015.

[8] W. Nan, Z. Xiaotong, "Related Study of the Financial and Urbanization Based on the PVAR Model," Information Science. Beijing, pp. 15181523, October 2011.(In Chinese)

[9] L. Yifu, "New Structural Economics: Reconstructing the Framework of Development Economics," China Economic Quarterly. Beijing, pp. 1-32, January 2010.(In Chinese) 